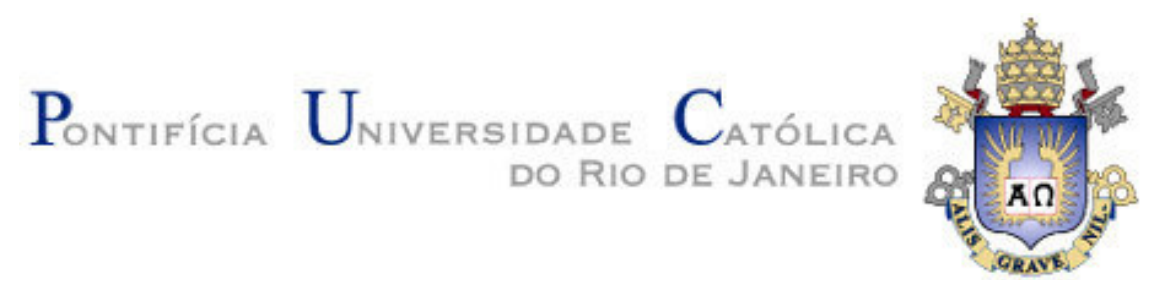

Amanda Fonseca Rodrigues

\title{
O Corpo na Constituição do Psíquico
}

Dissertação apresentada como requisito parcial para obtenção do título de Mestre pelo Programa de Pós-Graduação em Psicologia Clinica da PUCRio.

Orientadora: Profa.Monah Winograd 


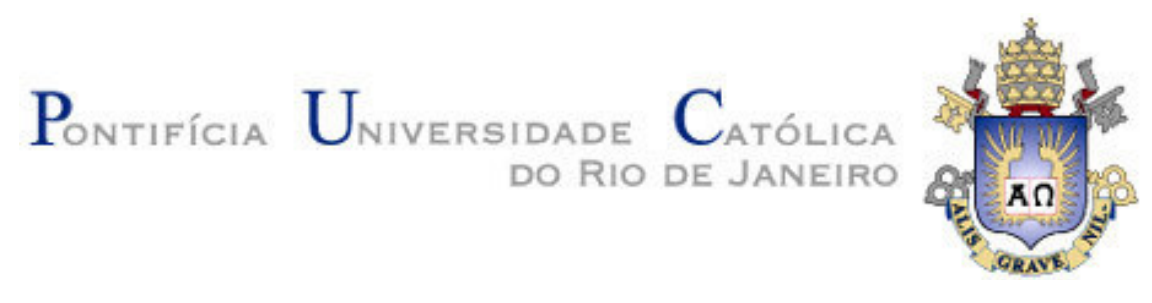

Amanda Fonseca Rodrigues

O Corpo na Constituição do Psíquico

Dissertação apresentada como requisito parcial para obtenção do título de Mestre pelo Programa de Pós-Graduação em Psicologia Clínica da PUC-Rio. Aprovada pela Comissão Examinadora abaixo assinada.

Profa. Monah Winograd Orientadora Departamento de Psicologia - PUC-Rio

Profa.Sara Kislanov Departamento de psicologia - PUC-Rio

Profa. Ivanise Fontes

Autônoma

Prof. Paulo Fernando Carneiro de Andrade Coordenador Setorial de Pós-Graduação e Pesquisa do Centro de Teologia e Ciências Humanas - PUC-Rio

Rio de Janeiro, 28 de abril de 2010 
Todos os direitos reservados. É proibida a reprodução total ou parcial do trabalho sem autorização da universidade, do autor e do orientador.

\section{Amanda Fonseca Rodrigues}

Graduado em Psicologia pela Puc-Rio em 2004 e pós Graduada em Saúde Mental e Desenvolvimento Infanto-Juvenil pela SCMRJ em 2006

Ficha Catalográfica

Rodrigues, Amanda Fonseca

O corpo na constituição do psíquico / Amanda Fonseca Rodrigues ; orientadora: Monah Winograd. $-2010$.

154 f. ; $30 \mathrm{~cm}$

Dissertação (Mestrado em Psicologia)-Pontifícia Universidade Católica do Rio de Janeiro, Rio de Janeiro, 2010.

Inclui bibliografia

1. Psicologia - Teses. 2. Corpo. 3. Nascimento psíquico. 4. Eu. 5. Pele. 6. Troca sensorial. I. Winograd, Monah. II. Pontifícia Universidade Católica do Rio de Janeiro. Departamento de Psicologia. III. Título.

CDD: 150 
Aos meus pais, Heloisio e Cristina, a quem devo a vida e toda minha formação enquanto sujeito. Meu reconhecimento e gratidão pelo amor incondicional. 


\section{Agradecimentos}

À minha querida orientadora, Monah Winograd, pela dedicação, confiança e incentivo na realização deste trabalho.

Ao CNPq e à PUC-Rio, pelos auxílios concedidos, sem os quais este trabalho não poderia ser realizado.

Aos meus pais, pelo amor incondicional, pela educação, pelo incentivo e por serem exemplos em minha vida.

Aos meus irmãos e cunhados, Juliana e Thiago, Thomaz e Fernanda pelo apoio e paciência que tiveram comigo ao longo da produção deste trabalho.

Aos meus sobrinhos Felipe e Maria Antonieta por trazerem alegria a minha vida.

À minha querida avó Zezé, por ser meu anjo da guarda.

À minha querida amiga Larissa Bauer, pela amizade, carinho e confiança ao longo de todos esses anos.

A todos meus amigos do mestrado, em especial Elen Coutinho e Milena Vasconcelos pelo apoio e trocas enriquecedoras.

A todos os meus amigos, que por muitas vezes me ouviram, auxiliaram e tornaram minha vida mais leve e prazerosa.

A Deus, que ilumina meus pensamentos e meu caminho.

Aos professores da Comissão Examinadora. 


\section{Resumo}

Rodrigues, Amanda Fonseca; Winograd, Monah. O Corpo na Constituição do Psíquico. Rio de Janeiro, 2010. 154p. Dissertação de Mestrado - Departamento de Psicologia, Pontifícia Universidade Católica do Rio de Janeiro.

Ao nascer nos encontramos em uma solidão primordial que é aliviada com o encontro do corpo materno. Ao mesmo tempo precisamos também de alguém que assegure o bem-estar e a sobrevivência do nosso próprio corpo, enquanto dispomos de tempo para crescer e amadurecer. A primeira forma de comunicação que permite esse encontro tão fundamental para a dupla mãe-bebê ocorre de modo visceral através das experiências corpo a corpo. Desse modo, o corpo constitui não só nossa primeira forma de expressão, como também o meio através do qual entramos em contato com o mundo externo e com o nosso próprio mundo interno, repleto de necessidades e desejos. A mãe, inicialmente, tem a função de tornar as estimulações corporais toleráveis, para que o bebê possa ter um desenvolvimento saudável, sem nenhuma interrupção prejudicial à sua continuidade de existência. Portanto, este trabalho visa demonstrar o papel preponderante do corpo na constituição daquilo que nos tornamos, na medida em que a quantidade e a qualidade das trocas e experiências sensoriais deixam marcas significativas que serão levadas ao longo da vida. São enfatizadas principalmente as experiências que ocorrem entre o corpo da mãe e o corpo do bebê, já que, no início, não existe separação entre o eu e o não-eu, e a trajetória para se conquistar a percepção dessa distinção é imprescindível para nos tornarmos sujeitos. As referências básicas que dão consistência ao eixo teórico deste trabalho são o conceito do eu corporal de Freud; a importância dada por Winnicott ao vínculo mãe-bebê, como assegurador da saúde mental; o conceito do eu-pele desenvolvido por Anzieu; a importância da tomada de consciência gradativa da separação física da mãe e os efeitos apontados por Tustin quando esta separação ocorre de forma traumática.

\section{Palavras-chave}

Corpo; nascimento psíquico; eu; pele; troca sensorial. 


\section{Abstract}

Rodrigues, Amanda Fonseca; Monah Winograd. The Body in the Constitution of Psychic. Rio de Janeiro, 2010. 154p. MSc. Dissertation Departamento de Psicologia, Pontifícia Universidade Católica do Rio de Janeiro.

As we are born we find ourselves in primordial loneliness which it is relieved with the meeting of the mother's body. At the same time we also need someone to ensure the well-being and the survival of our own body, while there is time for us to grow and to mature. The first kind of communication that allows this meeting so fundamental for the couple mother-baby occurs in a visceral way through the experience body to body. This way, the body is not only our first form of expression, but also the way by which we get in touch with the outside world and our own inner world, full of needs and desires. The mother initially, has the duty of making the body stimulation tolerable for the baby to have a healthy development, without any interruption detrimental to their continued existence. Therefore, this study demonstrates the role of the body in the constitution of what we become, as far as the quantity and quality of exchanges and sensory experiences leave significant marks that will be taken lifelong. Experiences that occur between the mother's body and the baby's body are mainly emphasized, since in the beginning, there is no separation between self and non-self, and the path to achieve the perception of this distinction is essential for us to become a person. The basic references that makes the theoretical basis of this study consistent are the Freud's concept of body-ego; the importance Winnicott gives to the link mother-baby, as a granter of the mental health; the concept of self-skin developed by Anzieu; the importance of the gradual awareness of the physical separation from the mother and the effects mentioned by Tustin when this separation occurs in a traumatic way.

\section{Keywords}

Body; psychic birth; ego; skin; sensory exchange. 


\section{Sumário}

1.Introdução

Parte I - A Constituição do Psiquismo em Freud

2. O Eu e o Corpo no Projeto 14

2.1. O problema da quantidade 14

2.2. A introdução da consciência e o problema da qualidade 18

2.3. O outro na origem da experiência de satisfação 22

2.4. O primeiro esboço de eu 25

3. O Eu e o Corpo na Metapsicologia 29

3.1. O conceito de pulsão e a relação entre corpo e psiquismo 29

3.2. Sexualidade Infantil: o problema do apoio e a noção de zona erógena

3.3. Do autoerotismo ao narcisismo secundário $\quad 37$

4. A Virada de XX 43

4.1. A constituição do eu 43

4.2. Os princípios que regem o funcionamento psíquico 52

Parte II - A constituição do psiquismo e o encontro corpo a corpo

5. O materno e o vir a ser 63

5.1. A vida emocional da mãe 63

5.2. O vir a ser $\quad 72$

5.3. A experiência de mutualidade 83

5.4. O ambiente facilitador: provisão ambiental e saúde mental 85

5.4.1. O Potencial herdado consolidado pelo cuidado materno 85

5.4.2. O holding, handling, apresentação de objeto - integração, personalização e realização 89

6. A dimensão corporal na origem do psíquico 102

6.1. A relação entre mente e corpo 102

6.1.1 A problemática mente-corpo para Freud 102

6.1.2 O auto-engendramento corpo-psique 112

6.2. O Eu-Pele 117

6.2.1. A função do eu-pele 117

6.2.2. A origem do eu-pele 126

6.3. O desenvolvimento da imagem corporal a partir de substâncias líquidas e gasosas $\quad 134$

6.4. As falhas na separação corporal: A cápsula autista 137

$\begin{array}{lr}\text { 7. Conclusão } & 145\end{array}$

$\begin{array}{lr}\text { 8. Referência Bibliográfica } & 150\end{array}$ 